\title{
Geographical genetics of Pseudoplatystoma punctifer (Castelnau, 1855) (Siluriformes, Pimelodidae) in the Amazon Basin
}

\author{
M.P.C. Telles ${ }^{1}$, R.G. Collevatti ${ }^{1}$, R.S. Braga ${ }^{1}$, L.B.S. Guedes ${ }^{1}$, T.G. Castro ${ }^{1}$, \\ M.C. Costa ${ }^{2}$, N.J. Silva-Júnior ${ }^{2,3}$, R.B. Barthem ${ }^{4}$ and J.A.F. Diniz-Filho ${ }^{5}$ \\ ${ }^{1}$ Laboratório de Genética \& Biodiversidade, Instituto de Ciências Biológicas, \\ Universidade Federal de Goiás, Goiânia, GO, Brasil \\ ${ }^{2}$ Systema Naturae Consultoria Ambiental LTDA, Goiânia, GO, Brasil \\ ${ }^{3}$ Departamento de Biologia, Pontifícia Universidade Católica de Goiás, \\ Goiânia, GO, Brasil \\ ${ }^{4}$ Departamento de Zoologia, Museu Paraense Emílio Goeldi, Belém, PA, Brasil \\ ${ }^{5}$ Departamento de Ecologia, Instituto de Ciências Biológicas, \\ Universidade Federal de Goiás, Goiânia, GO, Brasil \\ Corresponding author: M.P.C. Telles \\ E-mail: tellesmpc@gmail.com
}

Genet. Mol. Res. 13 (2): 3656-3666 (2014)

Received June 6, 2013

Accepted October 20, 2013

Published May 9, 2014

DOI http://dx.doi.org/10.4238/2014.May.9.8

\begin{abstract}
Geographical genetics allows the evaluation of evolutionary processes underlying genetic variation within and among local populations and forms the basis for establishing more effective strategies for biodiversity conservation at the population level. In this study, we used explicit spatial analyses to investigate molecular genetic variation (estimated using 7 microsatellite markers) of Pseudoplatystoma punctifer, by using samples obtained from 15 localities along the Madeira River and Solimões, Amazon Basin. A high genetic diversity was observed associated with a relatively low $F_{\mathrm{ST}}(0.057 ; \mathrm{P}<0.001)$, but pairwise $F_{\mathrm{ST}}$ values ranged from zero up to 0.21 when some pairs of populations were compared. These $F_{\mathrm{ST}}$ values
\end{abstract}


have a relatively low correlation with geographic distances $(\mathrm{r}=0.343$; $\mathrm{P}=0.074$ by Mantel test), but a Mantel correlogram revealed that close populations (up to $80 \mathrm{~km}$ ) tended to be more similar than expected by chance $(\mathrm{r}=0.360 ; \mathrm{P}=0.015)$. The correlogram also showed a exponential-like decrease of genetic similarity with distance, with a patch-size of around $200 \mathrm{~km}$, compatible with isolation-by-distance and analogous processes related to local constraints of dispersal and spatially structured levels of gene flow. The pattern revealed herein has important implications for establishing strategies to maintain genetic diversity in the species, especially considering the threats due to human impacts caused by building large dams in this river system.

Key words: Freshwater fish; Genetic diversity; Mantel test; Microsatellite; Population genetic structure; Spatial autocorrelation

\section{INTRODUCTION}

Geographical genetics aim to analyze patterns of genetic variation within or among populations by using explicit spatial analysis techniques that might be helpful to understand the ecological and evolutionary processes underlying such patterns (see Epperson, 2003; Diniz-Filho and Bini 2011). Starting from early applications of spatial autocorrelation analysis and Mantel tests (Sokal and Oden, 1978a,b; Sokal, 1979), the field later started applying more sophisticated statistical analyses, tested these procedures with simulation experiments, and developed more precise theoretical basis (see Epperson, 2003; Guillot et al., 2009 for reviews). More recently, the combination of genetic data and landscape features formed the field of landscape genetics (Manel et al., 2003; Holderegger and Wagner, 2008) that allows a better understanding of processes such as dispersal and gene flow patterns, with important conservation implications (Manel et al., 2010). All these fields, including geographical, landscape, and conservation genetics, are linked by both theoretical reasoning and use of similar statistical tools for spatial analysis (see Diniz-Filho et al., 2008; 2009).

Freshwater fish provide interesting opportunities for geographical genetic studies because, despite apparent habitat continuity and high dispersal, population structure can appear due to complex life cycles and migration (as in natal homing behavior, see Telles et al., 2011) or to hierarchical structure of aquatic systems in basins (Landeiro et al., 2011). Given the wide interference of human activities with aquatic environments affecting their spatial connection, such as dam building, as well as the importance of both water and fish as natural resources, the importance of population analysis of fish species becomes apparent.

Pseudoplatystoma punctifer (Castelnau, 1855; Siluriformes, Pimelodidae) is a large freshwater catfish, widely distributed in the Amazon Basin around the Amazon/Solimões River and is one of the most commercially important species in Amazon Basin (see also Crepaldi et al., 2006). It is a carnivore and migratory species, and some studies with a related species (Pseudoplatystoma corruscans) suggest a possible homing behavior associated with the migration patterns (see Barthem and Goulding, 1997; Pereira et al., 2009). Some previous studies investigated population genetic patterns in species of the genus Pseudoplatystoma, including Revaldaves et al. (2005), who developed microsatellite 
primers for P. corruscans and tested its transferability to other species, including Pseudoplatystoma fasciatum (which is closely related, or even completely overlapped, with $P$. punctifer (see Buitrago-Suarez and Burr, 2007; Torrico et al., 2009; Carvalho-Costa et al., 2011). Saulo-Machado et al. (2011) recently developed specific microsatellite markers for P. punctifer and described some genetic parameters within a local population. Pereira et al. (2009) recently showed that a significant population differentiation occurred among local populations of $P$. corruscans, with an $F_{\mathrm{ST}}$ around $8 \%$ and a significant spatial pattern in genetic differentiation according to Mantel test, by using 6 local populations (and interpreted such patterns as a consequence of homing behavior). More recently, Carvalho et al. (2012) reported significant evolutionary units for P. corruscans from Paraná-Paraguay Basin compared with a population from São Francisco Basin.

In this study, we used explicit spatial methods to evaluate the population genetic structure of P. punctifer along the Madeira and Solimões Rivers in the Amazon Basin. The analyses were performed using microsatellite markers developed by Revaldaves et al. (2005) and allowed a better understanding of the evolutionary processes underlying genetic variation in the species, providing the basis for establishing optimal conservation strategies to maintain genetic variability of the species.

\section{MATERIAL AND METHODS}

\section{Data}

We analyzed samples of $P$. punctifer collected from 15 localities (populations in a loose sense, hereafter), mainly along the Madeira River and a few in the low Solimões River, close to Manaus, all in the Amazon Basin (Table 1; Figure 1). In these localities, a total of 180 individuals were collected, with sample sizes ranging from 3 to 76 . We followed the taxonomic revision by Buitrago-Suarez and Burr (2007), who define this as a valid species for the Amazon/Solimões Basin and differentiated it from P. fasciatum, both geographically and morphologically. However, other more recent reviews and molecular phylogenetic analyses suggest that only P. fasciatum is a valid taxa (Torrico et al., 2009) or use P. fasciatum in a broad sense, including P. punctifer as a unit inside the later (Carvalho-Costa et al., 2011).

Genomic DNA was extracted from ethanol-fixed tissues following the protocol of Taggart et al. (1992). Seven microsatellite primers designed for P. corruscans Revaldaves et al. (2005; Table 2) were used. The genotyping experiments were performed in $15 \mu \mathrm{L}$ reaction volume containing $15 \mathrm{ng}$ template DNA, $260 \mu \mathrm{M}$ each primer, $1 \mathrm{U}$ Taq DNA polymerase (Phoneutria, BR), $210 \mu \mathrm{M}$ each dNTP, $2.16 \mathrm{mg}$ bovine serum albumin (BSA), and $1 \mathrm{X}$ reaction buffer $\left(10 \mathrm{~mm}\right.$ Tris- $\left.\mathrm{HCl}, \mathrm{pH} 8.3,50 \mathrm{~mm} \mathrm{KCl}, 1.5 \mathrm{~mm} \mathrm{MgCl}_{2}\right)$. All PCR amplifications were performed in a 9700 thermal cycler (Applied Biosystems, CA, USA) by using the following conditions: $95^{\circ} \mathrm{C}$ for $5 \mathrm{~min}$ (one cycle), $94^{\circ} \mathrm{C}$ for $1 \mathrm{~min}, 52^{\circ} \mathrm{C}$ to $64^{\circ} \mathrm{C}$ (see Table 1 ) for $1 \mathrm{~min}, 72^{\circ} \mathrm{C}$ for $1 \mathrm{~min}\left(30 \mathrm{cycles}\right.$ ); and $72^{\circ} \mathrm{C}$ for $7 \mathrm{~min}$ (one cycle). Forward primers were labeled with fluorescent dye (NED, 6-Fam, and Hex; Applied Biosystems). Amplified fragments were submitted to capillary electrophoresis at $9 \mathrm{~V}, 60^{\circ} \mathrm{C}$ for $22 \mathrm{~min}$ in the automated DNA sequencer ABI 3100 Genetic Analyzer from Applied Biosystem $^{\mathrm{TM}}$, and fragments were automatically sized using the GeneMaper ${ }^{\circledR} \mathrm{v} 4.1$ software (Applied Biosystems) 
Table 1. Sampling localities and genetic characterization of Pseudoplatystoma punctifer populations.

\begin{tabular}{|c|c|c|c|c|c|c|}
\hline No. & Population & $\mathrm{N}$ & $A$ & $A R$ & $H_{\mathrm{E}}$ & $f$ \\
\hline 1 & Madeira River (Porto Velho/RO) & 11 & 7 & 3.8 & 0.776 & 0.164 \\
\hline 2 & Madeira River (Porto Velho/RO) & 76 & 10 & 3.4 & 0.680 & $0.254^{*}$ \\
\hline 3 & Mamoré River (Guajará-Mirim/RO) & 9 & 5 & 3.1 & 0.658 & $0.324 *$ \\
\hline 4 & Purus River (Lábrea/AM) & 30 & 9.7 & 3.7 & 0.727 & $0.247^{*}$ \\
\hline 5 & Karipunas River (Porto Velho/RO) & 11 & 5.7 & 3.2 & 0.666 & $0.260^{*}$ \\
\hline 6 & Igarapé São Simão (Porto Velho/RO) & 8 & 5.8 & 3.6 & 0.743 & 0.208 \\
\hline 7 & São Lourenço River (Porto Velho/RO) & 5 & 5 & 3.8 & 0.811 & 0.366 \\
\hline 8 & Abunã River (Fortaleza do Abunã/RO) & 3 & 2.8 & 2.8 & 0.571 & -0.083 \\
\hline 9 & Mamoré Foz do rio Sotério River (Costa Marques/RO) & 4 & 2.7 & 2.5 & 0.553 & 0.032 \\
\hline 10 & Madre de Dios River (Santo Pablo/BOL) & 3 & 2.8 & 2.8 & 0.714 & $0.600 *$ \\
\hline 11 & Madre de Dios River (Independência/BOL) & 6 & 4.7 & 3.4 & 0.757 & 0.277 \\
\hline 12 & Alto Rio Solimões (Codajás/AM) & 3 & 3.1 & 3.1 & 0.714 & $0.400 *$ \\
\hline 13 & Madeira River (Porto Velho/RO) & 4 & 4.7 & 4 & 0.839 & 0.106 \\
\hline 14 & Amazonas River (Manaus/AM) & 4 & 4.7 & 4 & 0.833 & 0.400 \\
\hline 15 & Guaporé River (Costa Marues/RO) & 3 & 2.8 & 2.8 & 0.583 & 0.347 \\
\hline
\end{tabular}

$\mathrm{N}=$ number of individuals; $A=$ mean observed number of alleles; $A R=$ allelic richness by rarefaction; $H_{\mathrm{E}}=$ expected heterozigosity and $f=$ fixation index. *Significant at the 0.05 level.

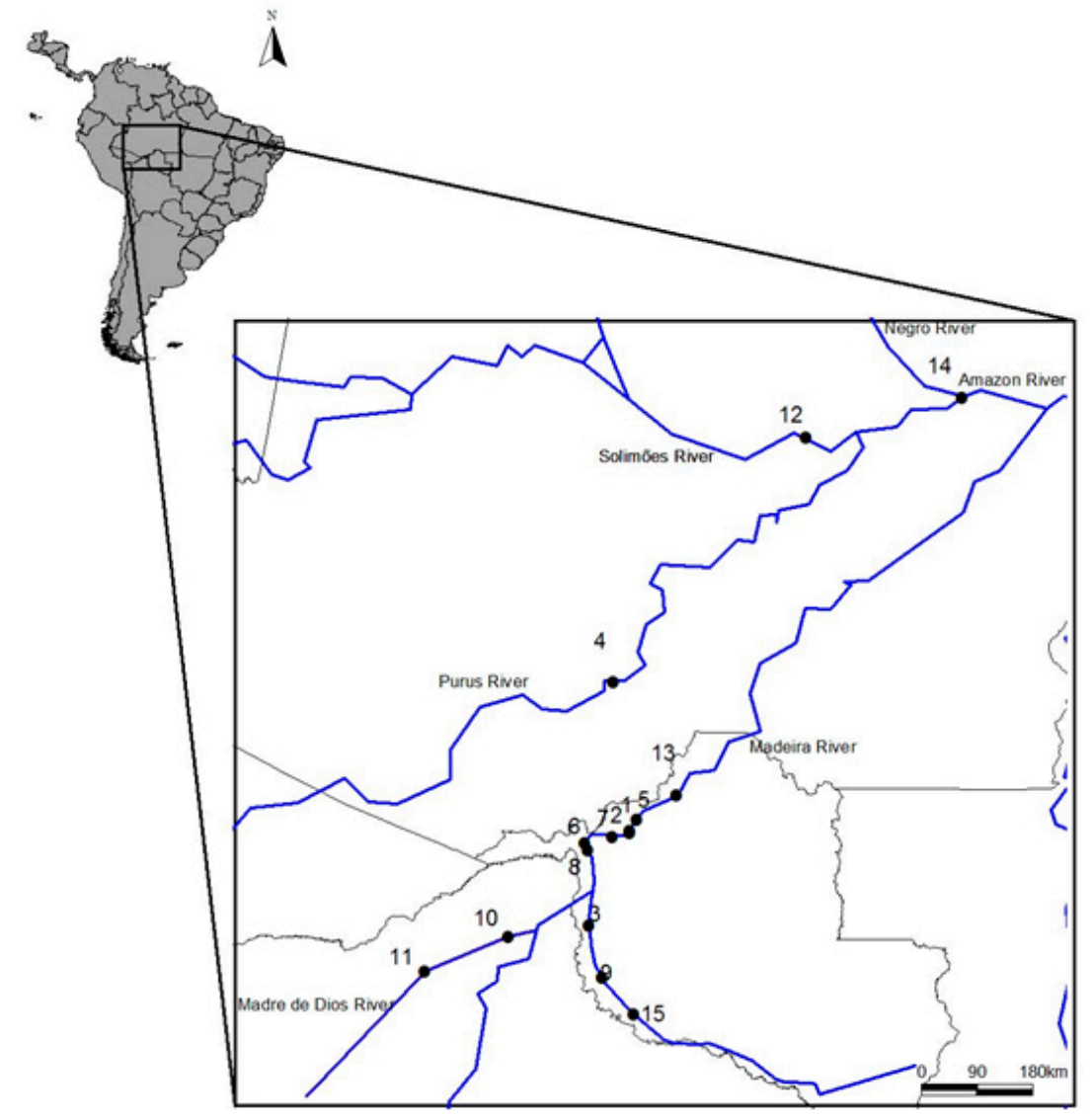

Figure 1. Localities from which samples of Pseudoplatystoma punctifer were obtained for the molecular analyses. 
Table 2. Microsatellite panels (1 and 2), markers (locus), forward primer sequence, fluorescent dye and annealing temperature prime (TA) used in the study.

\begin{tabular}{|c|c|c|c|c|c|}
\hline No. & Marker & Primer sequence & Fluorescente dye & $\mathrm{TA}\left({ }^{\circ} \mathrm{C}\right)$ & Multiplex \\
\hline 1 & Pcor $1-\mathrm{F}$ & AAACCCGAGGATAACCAGTC & 6-FAM & 64 & 1 \\
\hline 2 & Pcor 2 - F & GATATGCAAATAAGAAGGTC & 6-FAM & 58 & \\
\hline 3 & Pcor 5 - F & GACTAAGATTACACAGAGATTC & NED & 60 & \\
\hline 4 & Pcor 8 - F & ACACCATACGCACACACTCG & HEX & 62 & \\
\hline 5 & Pcor 7 - F & ATGCTGGGATACGCTCAGAC & NED & 64 & 2 \\
\hline 6 & Pcor $10-\mathrm{F}$ & TTTAAGACAGCACAGCCTGTGGGG & 6-FAM & 62 & \\
\hline 7 & Pcor $21-\mathrm{F}$ & TCACCGAGAGGTCTGACCATGA & HEX & 64 & \\
\hline
\end{tabular}

\section{Data Analysis}

Standard descriptive statistics of genetic parameters, including number of alleles (A), allelic richness by rarefaction (RA), observed and expected heterozigosities $\left(H_{\mathrm{O}}\right.$ and $\left.H_{\mathrm{E}}\right)$, and fixation indices $(f)$ were obtained for each local population by using the FSTAT 2.9.3.2 software (see Goudet, 2002). Following Telles et al. (2011), we tested the correlation between these metrics and geographic distance from a fixed point in the basin, to determine a reduction in genetic diversity (taking into account the variation in sample sizes).

Population structure was analyzed using Weir's (1996) analysis of variance of allele frequencies, allowing obtaining analogous of Wright's $F$-statistics $\left(F_{\mathrm{ST}}, F_{\mathrm{IS}}\right.$, and $\left.F_{\mathrm{IT}}\right)$. Parwise $F_{\mathrm{ST}}$ between localities was also obtained and was the basis for further spatial analyses by using Mantel tests (see below).

Spatial patterns were analyzed using Mantel test (Sokal, 1979; Manly, 1985, 1997), which is actually a matrix correlation between genetic $\left(F_{\mathrm{ST}}\right)$ and geographic distances tested by matrix randomization. The statistical significance of Mantel's coefficient (Pearson's correlation among matrices) was tested using 5000 random permutations. However, recent analyses (e.g., Perez et al., 2010; Legendre and Fortin, 2010) showed low statistical power of Mantel test. An unbiased and more informative analysis for evaluating spatial patterns in $F_{\mathrm{ST}}$ is building a Mantel correlogram, in which $F_{\mathrm{ST}}$ is compared with model matrices, in which 1 indicates if the pairs of local populations are connected at a given distance, and zero elsewhere. Here, 7 model matrices were built, linking populations situated at increasing geographical distances. Mantel tests and correlograms were performed in SAM 4. 0 (Rangel et al., 2010; see www.ecoevol.ufg.br/sam).

\section{RESULTS}

There was a high level of within population polymorphism in P. punctifer (Table 1), with mean number of alleles varying from 2.7 to 10 , although allelic richness was noted in localities (i.e., taking into account the variation in sample sizes), with values per loci ranging from 2.5 to 4 (although, as expected due to large variations in sample size, the rarefacted number varied less). For each of the 7 markers (loci), there was a considerable variation in Hardy-Weinberg (HW) equilibrium levels, and some of the local populations showed very high fixation indices $f$, indicating deviations from equilibrium. Expected heterozigosity was very high in local populations, ranging from 0.553 to 0.839 . A high global value of $f(0.254 ; \mathrm{P}$ $<0.05$ ) was noted, with values within local populations ranging from 0 to 0.6 , indicating nonrandom mating and low effective population sizes (similar to those found by de Abreu et al., 2009 and Pereira et al., 2009 for related species). 
The correlation between within-locality genetic parameters and distance from a fixed point were not significant, although correlation with RA was more negative and only marginally significant $(r=-0.428 ; P=0.144)$. This indicates a lack of strong decrease in genetic diversity toward waterheads (even after taking into account variation in sample size, by using the rarefied richness).

There was a significant differentiation among local populations, with an overall $F_{\mathrm{ST}}$ of $0.057(\mathrm{P}<0.01)$. However, pairwise $F_{\mathrm{ST}}$ between local populations varied around this overall value, ranging from values close to zero (actually -0.048 , due to sampling issues) up to 0.214 (between local population of Abunã River and upper Solimões). In general, pairwise $\mathrm{F}_{\mathrm{ST}}$ values were only marginally correlated with geographic distances at logarithmic scale by Mantel test ( $\mathrm{r}$ $=0.342 ; \mathrm{P}=0.064$ with 1000 permutations; Figure 2A). However, Mantel correlogram showed a significant correlation $\left(\mathrm{r}=0.360 ; \mathrm{P}=0.012\right.$ with 1000 permutations) between $F_{\mathrm{ST}}$ and connections at the smallest distance class $(0<\mathrm{D}<70 \mathrm{~km})$; the correlations stabilized around nonsignificant values after this initial distance class up to $200 \mathrm{~km}$ (Figure 2B). However, despite non-significant, there was an increase in autocorrelation at the fourth distance class, suggesting the presence of 2 "bumps" of genetic variability in space (see Legendre and Legendre, 2012).
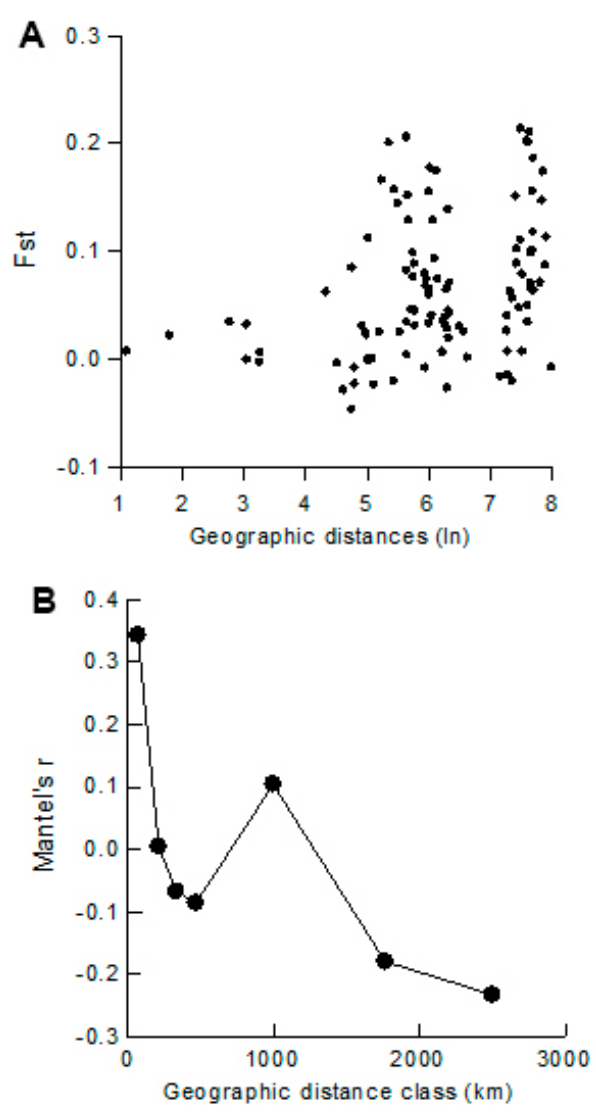

Figure 2. Relationship between pairwise $F_{\mathrm{ST}}$ and geographic distance among samples (Mantel correlation equal to $0.342 ; \mathrm{P}=0.064$ with 1000 permutations) $(\mathbf{A})$ and Mantel correlogram with 7 distance classes, revealing high positive autocorrelation in the small geographic distances $(\mathbf{B})$. 


\section{DISCUSSION}

\section{Population differentiation in P. punctifer}

Our analyses of $P$. punctifer revealed a significant genetic diversity both within and among populations throughout the Madeira, and for a few populations in the Solimões River in Manaus. Even after considering the large variation in sample sizes (with some local populations with only 3 individuals), it was possible to detect some interesting spatial patterns. Actually, there was no correlation $(\mathrm{r}=0.046 ; \mathrm{P}=0.88)$ between sample sizes and distance from Manaus; therefore, spatial patterns in genetic variation among local populations cannot be artifacts of sample sizes.

Despite the low level of genetic differentiation in the populations, some pairs of populations showed levels of differentiation as high as 0.21 . This value was within the range usually observed in other related species, such as P. corruscans in the Amazon basin and P. reticulatum in the Paraguay River (Pereira et al., 2009; Saulo-Machado et al., 2011; see also Carvalho et al., 2012 for a comparison of $P$. corruscans between Parana and São Francisco basins). However, in this study, $F_{\mathrm{ST}}$ values tended to be slightly correlated with geographical distances according to Mantel test. Nonetheless, this relationship was actually not linear (and this explained the lack of statistical significance of Mantel test), and correlograms revealed that closer populations in geographical space, at less than $200 \mathrm{~km}$, tend to be more genetically similar than expected by chance. The correlogram obtained for $P$. punctifer suggested an exponential decrease of genetic similarity with increasing geographic distance, in which close populations are genetically similar, but more distant populations are not necessarily the most different (the difference is random at broad geographical scales). This spatial pattern has been in turn associated with isolation - by-distance or stepping-stone models - in distinct spatial evolutionary and spatial scales (Sokal and Wartenberg, 1983; Hardy and Vekemans, 1999; Epperson, 2003). In general, the combination of statistically significant spatial heterogeneity (measured using $F_{\mathrm{ST}}$ and analogous statistics) and significant spatial patterns (evaluated here by Mantel test and correlograms) is indeed a strong indication of evolutionary processes driving geographic variation if based on molecular-genetic studies (rather than phenotypic data, which can be due to phenotypic plasticity only). If the analysis is coupled with a more specific evaluation of spatial patterns by correlograms, this can allow a more effective inference of evolutionary processes underlying genetic variation (Sokal and Oden, 1978b; Sokal et al., 1997).

An exponential decrease of genetic similarity with geographical distances, as observed here for $F_{\mathrm{ST}}$ along $P$. punctifer populations, reveals a local (rather than long-distance) structure, usually associated with processes that cause restricted dispersal, such as isolation-bydistance. Inferring the details and origins of the patterns might be difficult on the basis of this isolation-by-distance like pattern, for example, to distinguish if this is a current pattern caused by restricted gene flow or if it better reflects deep time evolutionary relationships among closer populations in geographical space, related to historical barriers. However, ruling out some other processes, such as long distance migration or adaptation to environmental variation might be possible (although this last process is unlikely for microsatellite markers). Moreover, the 2 bumps in the correlograms suggest 2 or more groups of slightly distinct mean genetic values.

Long distance migration or processes of range expansion (e.g., Excoffier and Ray, 2008) tend to generate more clinal patterns in which there is positive Mantel correlations at small geographical distances coupled with negative significant Mantel correlations at broad distance (So- 
kal and Oden, 1978b). Similarly, migration processes (and particularly homing behavior) tend to generate a clear and strong loss of genetic diversity within populations, which was not observed in this study (see Batista and Alves-Gomes, 2006; Batista et al., 2010; Telles et al., 2011).

Although Pereira et al. (2009) interpreted significant spatial structure of $R_{\mathrm{ST}}$ as evidence of homing behavior for $P$. corruscans, under homing behavior, although population differentiation is expected, a geographic spatial structure of genetic differentiation will occur only if there are other confounding historical factors and connections among the waterheads creating an exponential decrease (Telles et al., 2011). The decrease in genetic polymorphism (rarefied allelic richness) is expected under homing behavior, but it was not statistically significant in this study, despite the slight tendency or reduction or allelic richness toward waterheads. Due to the variation in sample sizes, our results actually do not rule the possibility that this decrease exists (because rarefied richness might not be able to deal with such strongly unbalanced sample size, as in our study). Nonetheless, the strong geographical pattern and exponential decrease seems to rule out migration and range expansion and consequently explanations should be focused on restricted gene flow among adjacent local populations, which also has important implications for conservation genetics of the species. Although Barthem and Goulding (1997) indicated that this species was migratory, our molecular analyses revealed that these migration and gene flow processes affect reproductive behavior and genetic variability at a relatively small geographical scale (i.e., not at Amazonian basin scale). Indeed, Isaac and Rufino (2000) suggested that migration of Pseudoplatystomas does not seem to occur throughout the entire basin, but mainly at a location in the main rivers toward smaller neighboring waterheads. This can explain the structure observed in this study, because this migration pattern would generate regional autocorrelation structure across the basin, and is also consistent with the 2 bumps in the correlograms.

\section{Conservation Implications}

The correlogram shape indicated thus that the local population of $P$. punctifer, despite inhabiting a continuous environment along the Madeira River, is locally structured and shows genetic differentiation at small geographical distances. As mentioned above, further analyses using mtDNA markers and a phylogeographical analyses based on a coalescent reasoning might be required for better understanding the origins of the observed patterns, as well as the relatively roles of restricted current and historical gene flows in this pattern. This is the basis of the phylogeographical definition of evolutionary significant units (ESUs) for improving the within-specific conservation strategies (see Moritz, 1994), but this has only been applied at broader geographical and taxonomic scales.

However, Diniz-Filho and Telles (2002; see also Diniz-Filho and Telles, 2006; DinizFilho and Bini, 2011) proposed a more general strategy for defining operational units for conservation for finer-scale, continuously distributed local populations, on the basis of autocorrelation. This approach clearly applies to P. punctifer, and the shape of the correlogram suggests that populations situated at distances smaller than $200 \mathrm{~km}$ tend to be genetically similar. This indicates that optimizing sampling strategies for ex-situ conservation (i.e., tissue collections or programs for monitoring fluctuations in genetic diversity as surrogates of demographic parameters) can be possible if this distance can be used as a minimum distance between samples. Alternatively, definition of operational units suggest that, for P. punctifer, would be necessary 
to maintain at least one local population preserved within intervals of $200 \mathrm{~km}$ and associated with known reproductive area to ensure the preservation of genetic diversity of the species in the region, on the basis of the genetic system analyzed herein. Indeed, because population differentiation in general is low, all populations are similar and generating cost-effective complementary analysis methods in all these conservation strategies is necessary.

\section{CONCLUSIONS}

Our analyses revealed significant spatial heterogeneity of molecular genetic variation in P. punctifer, coupled with short-distance spatial patterns. This combination reveals that local restrictions to dispersal exist, due to current or historical spatially structured levels of gene flow. Independent of the evolutionary processes underlying this pattern, there are important conservation implications for such findings. By considering the human impacts in the region, notably the establishment of large dams in the Amazon Basin, the patterns observed here should be viewed and interpreted with care. On one hand, long-distance migration and historical patterns of genetic differentiation can be ruled out, at least in the geographical extent analyzed in this study, and creates a relatively uniform population throughout the basin. On the other hand, limited gene flow suggests that impacts at large distances can disturb populations locally and eliminate parts of the genetic diversity of the species. Considering cost-benefit analysis and using the results of this study to define optimum strategies, it might be necessary to maintain viable populations and maintain genetic diversity at current levels.

\section{ACKNOWLEDGMENTS}

Study developed by Systema Naturae Consultoria Ambiental LTDA research group in the context of a project to study homing behavior in Neotropical fish threatened by governmental dam building programs in Amazonian basin and supported by "Consórcio Energia do Brasil". Research of M.P.C. Telles, R.G. Collevatti, and J.A.F. Diniz-Filho on geographical genetics has been supported by many productivity and research grants from CNPq and CAPES.

\section{REFERENCES}

Barthem RB and Goulding M (1997). Os Bagres Balizadores: Ecologia, Migração e Conservação de Peixes Amazônicos. Sociedade Civil Mamirauá and CNPq, Brasília.

Batista JS, Farias IP, Formiga-Aquino K and Sousa ACB (2010). DNA microsatellite markers for "dourada" (Brachyplatystoma rousseauxii, Siluriformes: Pimelodidae), a migratory catfish of utmost importance for fisheries in the Amazon: development, characterization and inter-specific amplification. Conserv. Genet. Resour. 2: 5-10.

Batista JS and Alves-Gomes JA (2006). Phylogeography of Brachyplatystoma rousseauxii (Siluriformes - Pimelodidae) in the Amazon Basin offers preliminary evidence for the first case of "homing" for an Amazonian migratory catfish. Genet. Mol. Res. 5: 723-740.

Buitrago-Suarez UA and Burr BM (2007). Taxonomy of the catfish genus Pseudoplatystoma Bleeker (Siluriformes: Pimelodidae) with recognition of eight species. Zootaxa 1512: 1-38.

Carvalho-Costa LF, Piorski NM, Willis SC, Galetti PM, Jr., et al. (2011). Molecular systematics of the neotropical shovelnose catfish genus Pseudoplatystoma Bleeker 1862 based on nuclear and mtDNA markers. Mol. Phylogenet. Evol. 59: 177-194.

Carvalho DC, Oliveira DAA, Beheregaray LB and Torres RA (2012). Hidden genetic diversity and distinct evolutionarily significant units in an commercially important Neotropical apex predator, the catfish Pseudoplatystoma corruscans. Conserv. Genet. 13: 1671-1675. 
Crepaldi DV, Faria PMC, Teixeira EA, Ribeiro LP, et al. (2006). O surubim na aquacultura do Brasil. Rev. Bras. Reprod. Anim. 30: 150-158.

de Abreu MM, Pereira LH, Vila VB, Foresti F, et al. (2009). Genetic variability of two populations of Pseudoplatystoma reticulatum from the Upper Paraguay River Basin. Genet. Mol. Biol. 32: 868-873.

Diniz-Filho JAF and Telles MPC (2002). Spatial autocorrelation analysis and the identification of operational units for conservation in continuous populations. Conserv. Biol. 16: 924-935.

Diniz-Filho JAF and Telles MPC (2006). Optimization procedures for establishing reserve networks for biodiversity conservation taking into account population genetic structure. Genet. Mol. Biol. 29: 207-214.

Diniz-Filho JAF, Telles MPC, Bonatto S, Eizirik E, et al. (2008). Mapping the evolutionary twilight zone: molecular markers, populations and geography. J. Biogeography 35: 753-763.

Diniz-Filho JAF and Bini LM (2011). Geographical patterns in biodiversity: towards an integration of concepts and methods from genes to species diversity. Natureza \& Conserv. 9: 179-187.

Diniz-Filho JA, Nabout JC, de Campos Telles MP, Soares TN, et al. (2009). A review of techniques for spatial modeling in geographical, conservation and landscape genetics. Genet. Mol. Biol 32: 203-211.

Epperson BK (2003). Geographical genetics. Princeton University Press, New Jersey.

Excoffier L and Ray N (2008). Surfing during population expansions promotes genetic revolutions and structuration. Trends Ecol. Evol. 23: 347-351.

Goudet J (2002). FSTAT, a program to estimate and test gene diversities and fixation indices (version 2.9.3.2). Available at [http://www.unil.ch/izea/softwares/fstat.html]. Accessed August 21, 2013.

Guillot G, Leblois R, Coulon A and Frantz AC (2009). Statistical methods in spatial genetics. Mol. Ecol. 18: 4734-4756.

Hardy OJ and Vekemans X (1999). Isolation by distance in a continuous population: reconciliation between spatial autocorrelation analysis and population genetics models. Heredity 83 ( Pt 2): 145-154.

Holderegger R and Wagner HH (2008). Landscape genetics. BioScience 58: 199-207.

Isaac VJ and Ruffino ML (2000). A estatística pesqueira no Baixo Amazonas: experiência do Projeto Iara. IBAMA, Coleção Meio Ambiente Série Estudos de Pesca 22: 201-223.

Landeiro VL, Magnusson WE, Melo AS, Espírito-Santo HMV, et al. (2011). Spatial eigenfunction analyses in stream networks: do watercourse and overland distances produce different results? Freshwater Biology 56: 1184-1192.

Legendre P and Legendre L (2012). Numerical Ecology, 3rd edn. Elsevier, Amsterdam.

Legendre P and Fortin MJ (2010). Comparison of the Mantel test and alternative approaches for detecting complex multivariate relationships in the spatial analysis of genetic data. Mol. Ecol. Resour. 10: 831-844.

Manel S, Schwartz MK, Luikart G and Taberlet P (2003). Landscape genetics: combining landscape ecology and population genetics. TREE 18: 189-197.

Manel S, Joost S, Epperson BK, Holderegger R, et al. (2010). Perspectives on the use of landscape genetics to detect genetic adaptive variation in the field. Mol. Ecol. 19: 3760-3772.

Manly BFJ (1985). The Statistics of Natural Selection. Chapman and Hall, London,

Manly BFJ (1997). Randomization, Bootstrap, and Monte Carlo Methods in Biology. Chapman and Hall, London.

Moritz C (1994). Defining ‘Evolutionarily Significant Units' for conservation. Trends Ecol. Evol. 9: 373-375.

Pereira LHG, Foresti F and Oliveira C (2009). Genetic structure of the migratory catfish Pseudoplatystoma corruscans (Siluriformes: Pimelodidae) suggests homing behavior. Ecol. Freshwater Fish 18: 215-225.

Perez SI, Diniz-Filho JA, Bernal V and Gonzalez PN (2010). Alternatives to the partial Mantel test in the study of environmental factors shaping human morphological variation. J. Hum. Evol. 59: 698-703.

Rangel TF, Diniz Filho JAF and Bini LM (2010). SAM: a comprehensive application for Spatial Analysis in Macroecology. Ecography (Copenhagen) 33: 46-50.

Revaldaves E, Pereira LHG, Foresti F and Oliveira C (2005). Isolation and characterization of microsatellite loci in Pseudoplatystoma corruscans (Siluriformes: Pimelodidae) and cross-species amplification. Mol. Ecol. Notes 5: 463465.

Saulo-Machado AC, Formiga KM, Ortiz MF, Sousa ACB, et al. (2011). Polymorphic microsatellite DNA markers for the Amazonian catfish Pseudoplatystoma punctifer (Siluriformes: Pimelodidae). Conservation Genetics Resources 3: 307-310.

Sokal RR and Oden NL (1978a). Spatial autocorrelation in biology. 1. Methodology. Biological J. Linnean Society 10: 199-228.

Sokal RR and Oden NL (1978b). Spatial autocorrelation in biology: 2. Some biological implications and four applications of evolutionary and ecological interest. Biological J. Linnean Society 10: 229-249.

Sokal RR (1979). Testing statistical significance of geographic variation patterns. Syst. Zool. 28: 227-232.

Sokal RR, Oden NL and Thomson BA (1997). A simulation study of microevolutionary inferences by spatial autocorrelation analysis. Biological J. Linnean Society 60: 73-93. 
Sokal RR and Wartenberg DE (1983). A test of spatial autocorrelation analysis using an isolation-by-distance model. Genetics 105: 219-237.

Taggart JB, Hynes RA, Prodöhl PA and Ferguson A (1992). A simplified protocol for routine total DNA isolation from salmonid fishes. J. Fish Biol. 40: 963-965.

Telles MP, Collevatti RG, da Costa MC, Barthem RB, et al. (2011). A geographical genetics framework for inferring homing reproductive behavior in fishes. Genetica 139: 243-253.

Torrico JP, Hubert N, Desmarais E, Duponchelle F, et al. (2009). Molecular phylogeny of the genus Pseudoplatystoma (Bleeker, 1862): biogeographic and evolutionary implications. Mol. Phylogenet. Evol. 51: 588-594.

Weir BS (1996). Genetic data analysis II. Sinauer Associates, Washington. 